\title{
血小板凝集反応の新しい解析法
}

東 照正* 橋本 正史* 垣下 栄三** 吉村 早苗**
小坂 博昭** 木村 信彦** 永井 清保**

\section{The New Method for Kinetics Analysis of Platelet Aggregation by Measurement of Numbers of Residual Single platelets in Aggregation Reaction}

\author{
Terumasa HIGASHI*, Masafumi HASHIMOTO*, Eizo KAKISHITA**, \\ Sanae YOSHIMURA**, Hiroaki KOSAKA**, \\ Nobuhiko KIMURA** and Kiyoyasu NAGAI**
}

Key words : platelet aggregation, new Imethod of kinetics analysis, electric particle counter, rate constant

The number of residual free single platelets was counted in the course of platelet aggregation reaction for the purpose of studying chemical kinetics analysis of platelet aggregation by ADP.

The change in number of single platelets agreed with the function :

$$
\begin{aligned}
& \text { single platelets } \stackrel{\mathrm{k}}{\longrightarrow} \text { aggregates } \\
& {[\mathrm{P}]=\left[\mathrm{P}_{0}\right] \mathrm{e}^{-\mathrm{kt}},\left([\mathrm{P}]: \text { the number of single platelets, }\left[\mathrm{P}_{0}\right]:\right. \text { the initial }} \\
& \text { number of single platelets, } \mathrm{k} \text { : rate constant, } \mathrm{t}: \text { time })
\end{aligned}
$$

and rate constant " $\mathrm{k}$ " was measured to know the degree of platelet aggregation. $[\mathrm{P}]$ was measured by electric particle counter (Coulter Counter Model ZBI) under the condition of aperture tube : $70 \mu$, aperture current : $1 / 4$, amplification : $1 / 4$, matching switch : $20 \mathrm{~K}$ and monometer position : $0.5 \mathrm{ml}$. Upper and lower thresholds were selected to include the main peak on platelet volume distribution curve.

By this method some results were obtained as follows. " $\mathrm{k}$ " was constant on the various concentrations of platelets from same blood. " $\mathrm{k}$ " changed in proportion to the degree of stir of reaction mixture. " $\mathrm{k}$ " was constant when ADP concentration was more than $10^{-6} \mathrm{M}$. But " $\mathrm{k}$ " was logarithmically decreased between $10^{-6}$ and $10^{-7} \mathrm{M}$ of $\mathrm{ADP}$, and got toward zero when $\mathrm{ADP}$ concentration was less than $10^{-7} \mathrm{M}$.

* 大阪大学医学部第一生理“ [个 $553_{\varepsilon}^{*}$ 大阪市北区中之島4-3-57), Department of Physicochemical Physiology, Medical School, Osaka University, Osaka, Japan.

** 兵庫医科大学第二内科, Internal Medicine, Hyogo College of Medicine, Hyogo, Japan. 


\section{緒言}

血小板凝集反応測定のために一般に広く用い られている分光学的検査法は, 粒子分散系での 透過光の変化をみており，得られる凝集曲線の 指標がどこまで確実に血小板凝集反応過程を反 映しているか問題があり，真の定量性を得るこ とは難しいとあいわれている11.

著者らはこれまでの本討議会において, ADP 凝集反応の分光学的測定における真の凝集能を 表わす指標をみつけるべく，反応速度論的考察 を加え若干の知見を得，報告してきた ${ }^{23)}$. し かしこれも従来からの反応速度論的解析之同 様, 凝集反応の進行と光散乱との関係が明確に 示されない限り検討すべき余地はなお残る.

そこで凝集反応の過程を凝集生成の面からで なく残る非凝集血小板数を測定することにより 反応を速度論的に解析できないかと考えた。

すなわち凝集反応を

(1) single platelets $\stackrel{\mathrm{k}}{\longrightarrow}$ aggregates なる反応
応を起とさせ，ADP 添加以後経時的に 5 秒毎 にこの反応液中より $0.1 \mathrm{~m} l$ をとり，速やかに $1.9 \%$ ホルマリン液 $1.0 \mathrm{~m} l$ と混合，凝集反応を 停止させ，それぞれの時点での反応状態を固定 した.

1. 視算法による single platelets の測定 single platelets 濃度 [P]の值を求めるため, 顕微鏡下で視算した。この成績を図 1 上段に示 す.

[P]は時間之と屯に指数函数的に減少し，乙 の場合 $8.3 \times 10^{4} / \mathrm{m} \mathrm{m}^{3}$ で一定になった。凝集後 に残ったての single plateletsは元々機能を果 さない血小板か，凝集塊からはがれて機能を失 ったものと考えられ，乙の值を差し引いて片対 数グラフに書くと，図 1 上段右図のごとくとな り(3)式を満足させる。

\section{2. 自動血球計数器による血小板の測定}

自動血球計数器を用いて非凝集血小板を測定 した. 非凝集血小板と凝集血小板を区別して測 定するためには粒子の大きさによって測定し分

By visual counting method
(2) $-\mathrm{d}[\mathrm{P}] / \mathrm{dt}=\mathrm{k}[\mathrm{P}] （ た$ だし $\mathrm{k}$ ：反応速度定数, [P] : single platelets の濃度) である。これは

(3) $[\mathrm{P}]=\left[\mathrm{P}_{0}\right] \mathrm{e}^{-\mathrm{kt}}$ （ただ $し\left[\mathrm{P}_{0}\right]$ : single platelets $の$ 初濃度， $\mathrm{t}$ : 経過時間) とな る.

すなわち，凝集反応時に経 時的に single platelets を測 定して行くと，その血小板固 有の凝集反応速度を表わす指 標が得られることになる.

\section{I. 方法と成績}

家鬼血液を $1 / 9$ 容クエン酸 ソーダと混じて $160 \mathrm{G} 10$ 分間 遠沈して血小板濃厚血漿 (PR $P$ ) を得，乙れを実験に用い た. PRP に $4.0 \times 10^{-4} \mathrm{M}$ の $\mathrm{ADP}$ を $1 / 10$ 容加えて凝集反
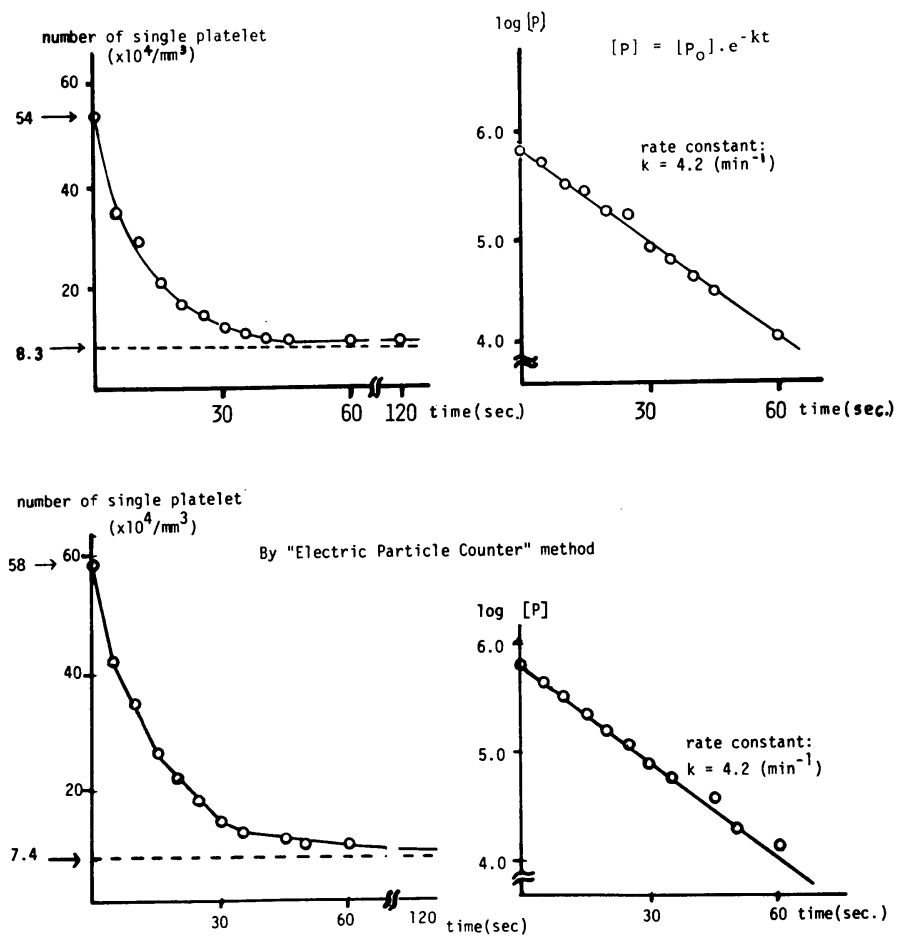

Fig. 1 Changes of free single platelet numbers during aggregation reaction induced by ADP. 


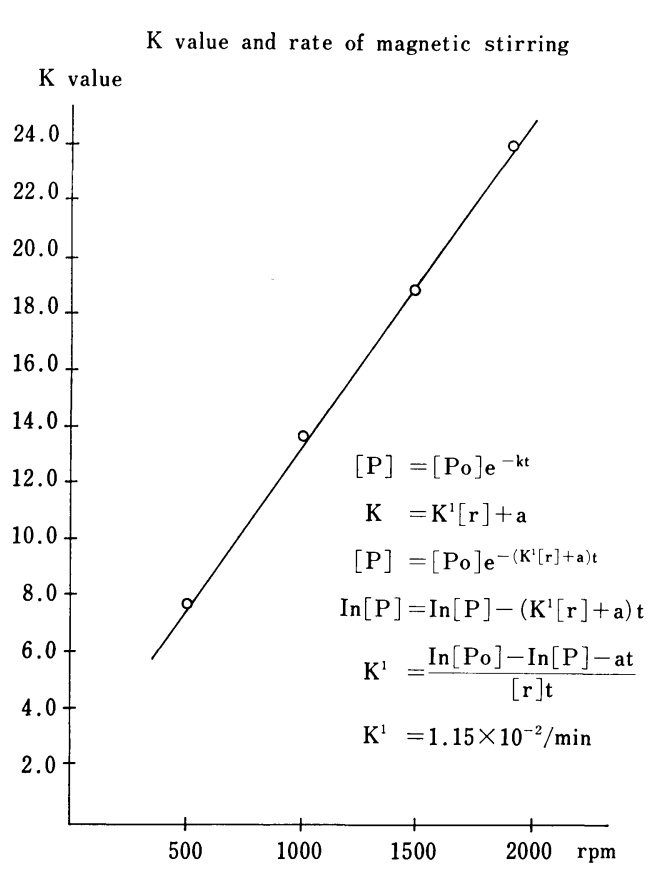

Fig. 2 The relationship between rate constant " $k$ " and rate of magnetic stirring.

けることのできる性質を利用すれば可能であ る.そこで測定には Coulter Counter Model ZBIを用いた。 aperture tube $70 \mu$ を用い, aperture current $1 / 4$, amplification $1 / 4$ の条件で測 定した。測定閾は試料になる血小板の大きさ， 測定条件により異なるがあらかじめ血小板粒度 分布を画いて main peak となる部分，すなわち 大体15〜35を選んだ。この条件下で凝集反応の 各時間毎の〔P]を計測したのが図 1 下段に示 すむのである.乙れは視算法で得られた成績と よく一致した。こうして得られた $\mathrm{k}$ はとあに $\mathrm{k}=4.2 / \mathrm{min}$ となった.

このととは先に想定した理論式を実験的に証 明したととになり，〔P〕すなわち single platelets の濃度測定に自動血球計数器が利用可能で あることを示している，そこで以後の実験には Coulter Counter を用いて行った.

\section{3. 血小板濃度の変化}

血小板濃度を変化させ他は同一条件で反応さ せ， $\mathrm{k}$ の変化をみた。 この場合は $\mathrm{k}$ に変化をみ ず初期血小板濃度に関係ないととを示した。

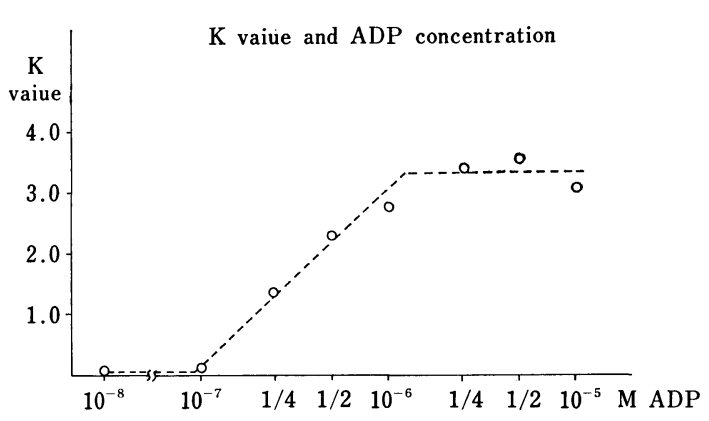

Fig. 3 The relationship between rate constant " $k$ " and ADP concentration.

\section{4. 凝集反応摫拌速度の変化}

凝集反応時の攪拌速度を変化させ，他は同一 条件で検討した．攪拌速度を変えると $\mathrm{k}$ は変化 し，攪挥速度と $\mathrm{k}$ との関係をみると図 2 のごと く比例関係が認められた。

$\mathrm{k}$ と攪拌速度 $[\gamma]$ との 関係をみると $\mathrm{k}=\mathrm{k}^{\prime}$ $[\gamma]+\mathrm{a} （ た た ゙ し ， \mathrm{k}^{\prime}$ : 攪䢁速度に関係する反応 速度定数, $[\gamma]$ ：攪拌速度， $\mathrm{a}:$ 定数）となる. これを元の式 $[\mathrm{P}]=\left[\mathrm{P}_{0}\right] \mathrm{e}^{-\mathrm{kt}}$ に代入し $[\gamma] に$ 関係する式にするととができる.

すなわち $[\mathrm{P}]=\left[\mathrm{P}_{0}\right] \mathrm{e}^{-\left(\mathrm{k}^{\prime}[r]+\mathrm{a}\right) \mathrm{t}}$ となる。

この場合, 図でみるごとく, $\mathrm{a}=2$ となるの で, $\mathrm{k}^{\prime}=1.15 \times 10^{-2} / \mathrm{min}$ となった。

\section{ADP 濃度の変化}

$\mathrm{ADP}$ 濃度を変化させて $[\mathrm{P}]$ の変化をみた。 各 $\mathrm{ADP}$ 濃度にて〔P]は片対数グラフ上で直 線的に変化した。乙れから各 ADP 濃度におけ る $\mathrm{k}$ を求め $\mathrm{ADP}$ 濃度と $\mathrm{k}$ の関係をみると 図3のごとくになった。すなわち $10^{-7} \mathrm{M}$ 以下 では $\mathrm{k}$ は 0 に近くなり $10^{-6} \mathrm{M}$ 以上では大体一 定の值をとり $10^{-7}$ と $10^{-6} \mathrm{M}$ の間で増加した.

\section{II. 考 按}

血小板凝集反応の反応速度論的解析は, いく つか試みられ ${ }^{4 \sim 6)}$, それぞれ反応形式の理解, 臨床応用などに一応の成果をみるととができる が，しかしいずれあ緒言で述べた問題を含みな お検討すべき点がある．著者らは凝集反応の初 速度を用いて凝集反応式をたで3，乙れにより 一定の反応速度定数を得るととを示した。

しかし初速度の分光学的測定は繁雑である. 
$10: 266$

そこで凝集反応を凝集過程での非凝集血小板数 の測定により反応速度を測定できないかと考え た.このために凝集反応の理論式を想定し，乙 れを実験的に証明し反応定数を得ることができ ることを示した。

この際, 非凝集血小板の测定のために，測定 対象粒子の大きさを限定して測定できる自動血 球計数器 (Coulter Counter Model ZBI) を利 用できることを示した。非凝集血小板の测定閾 值を決めるために，凝集反応を起させ経時的に ホルマリン固定した反応液の 粒度分布をみる と, main peak が時間ととあに低下していくの がみられ，したがってこの peak に相当する範 囲が非凝集血小板に相当すると判断した．との ようにして決めた閾値内の血小板数の変化と視 算で得た変化と一致するととから, 自動血球計 数器が利用できるととが判った。

このようにして $\mathrm{k}$ は血小板濃度に関係ないこ と, 攪拌速度 $[r]$ とは一定の比例関係がある ことが示された。また ADP 濃度との関係をみ ると $10^{-7} \mathrm{M}$ 以下では $\mathrm{k}$ は 0 に近くなり，10 $10^{-6} \mathrm{M}$ 以上では大体一定の值をとることがみられ， $10^{-7} \sim 10^{-6} \mathrm{M}$ の間で片対数グラフ上で直線関係 がみられた。この関係は初速度でみたあのとよ く似ており同様の解釈ができるあのと思う.

いずれにせよ本質的に同じあのをみているの であるから従来の分光学的解析と大きな違いは ないと思われるが，乙の方法では 1 つの parameterのみを追跡しており現象を simple に解析 し，方法論的にあ簡便である点実用性があり， より確実な定量的指標を得るととができると思
血 液 と脈管 第 10 巻 第 2 号

われ，今後さらに研究していきたい。

\section{結語}

自動血球計数器を用いて凝集反応の反応速度 を定量的に測定できるととを示し，乙の方法を 用いて関係する条件を一定にして血小板固有の 凝集能を表現する指標を得るととができる可能 性を示唆した。

\section{文献}

1) Born, G. V. R., et al.: Effects of numbers and sizes of platelet aggregates on the optical density of plasma. Nature, 215; 1027 〜 1029, 1967.

2) 東 照正, 他：ADP による血小板一次凝集の 反応速度論的考察一aggregometer で得た凝集 能の臨床的指標に対する検討. 血液と脈管,

8; 291 296, 1977.

3）東 照正, 他：ADP による血小板凝集反応の 解析. 血液と脈管, $9 ; 375 \sim 379,1978$.

4) 安部 英, 他：ADP 血小板凝集作用の分析 (第 2 報). 日血会誌， $36 ； 391,1973$.

5）西沢一郎, 他：血小板凝集曲線 の 反応速度論 的解析とその応用（種々の核酸関連物質の血 小板凝集反応への影響). 血液と脈管, 8；285 $\sim 289,1977$.

6）奥 史郎，他：ADP 凝集曲線の理論的実験的 一考察. 血液之脈管, 7; 1001 1006, 1976.

7) Rossi, E.C., et al.: Kinetic parameters of platelet aggregation as an expression of platelet responsiveness. Thrombos. Haemostas., 37 ; 283 290, 1977. 